\title{
Capítulo II \\ Sobreviviendo con la pipa: \\ drogas, violencia y conflictos interétnicos en el Paraíso \\ El resumen de una etnografía de la violencia urbana en un barrio de Quito-Ecuador
}

William Álvarez

\section{SciELO Books / SciELO Livros / SciELO Libros}

ÁLVAREZ, W. Sobreviviendo con la pipa: drogas, violencia y conflictos interétnicos en el Paraíso. El resumen de una etnografía de la violencia urbana en un barrio de Quito-Ecuador. In: URIBE TABORDA, S., and AGUILAR RODRÍGUEZ, F., coord. Etnografías: procesos, experiencias y resistencias sociales [online]. Quito: Editorial Abya-Yala, 2020, pp. 91-131. ISBN: 978-9978-10-506-1. http://doi.org/10.7476/9789978105740.0004.

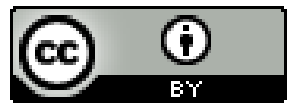

All the contents of this work, except where otherwise noted, is licensed under a Creative Commons Attribution 4.0 International license.

Todo o conteúdo deste trabalho, exceto quando houver ressalva, é publicado sob a licença Creative Commons Atribição 4.0.

Todo el contenido de esta obra, excepto donde se indique lo contrario, está bajo licencia de la licencia Creative Commons Reconocimento 4.0. 


\section{CAPÍtulo II \\ Sobreviviendo con la pipa: drogas, violencia y conflictos interétnicos en el Paraíso El resumen de una etnografía de la violencia urbana en un barrio de Quito-Ecuador}

William Álvarez

\section{Resumen}

El trabajo que aquí presento es la culminación de una investigación en el área de antropología urbana con casi un año de etnografía en un barrio céntrico de la ciudad de Quito-Ecuador. Espacio urbano reconocido por ser un punto histórico de violencia, venta callejera de drogas ilícitas como la pasta base de cocaína, marihuana y cocaína, además de ser un lugar de recepción para migrantes afrodescendientes (negros) de la costa pacífica (pobre) ecuatoriana. El objetivo principal de este proyecto es describir el por qué muchos de estos migrantes recurrían a la economía ilegal y qué otro tipo de prácticas económicas ellos debían realizar para sobrevivir en la ciudad. No obstante, este trabajo no sólo se reduce a la descripción de sus vidas precarias, sino también rastrear los orígenes de la violencia estructural y étnico/racial que sufre la población afrodescendiente a lo largo de la formación del Estado-nación. 
Palabras claves: Etnografía, estrategias de supervivencia, drogas, economía ilegal/informal, violencia.

\section{Introducción, el espacio físico/social y el problema}

Al llegar al barrio a eso de las 9 pm no contaba encontrarme con nadie, pues los conocidos que frecuentan la esquina ya no estaban. Sin embargo, tuve suerte, antes de llegar a mi puerta Richard y Patricio venían caminando del fondo de la calle, no dudé en llamarles, enseguida ellos me hicieron la venia. Durante esa noche que vivimos no me quedaba claro aún si Richard era un vendedor o un consumidor habitual de polvo. Por lo que he visto no fuma con frecuencia, lo hace circunstancialmente en compañía de sus amigos, Patricio es uno de ellos. Éste último fue quien propició económicamente el polvo que consumieron toda la noche.

Aquella mercancía duró poco, luego Richard nos pidió lo esperamos fuera de una puerta de metal medio abierta que dejaba ver un pasillo infinito y oscuro ¡Me parecía increíble que a pocos metros de mi casa se pudiera conseguir droga tan fácil! Al rato salió él y trajo consigo varias papeletas. De ahí caminamos a un parque, pero pasó la policía y nos advirtieron salir de ahí. Richard dice que ellos no joden, que los policías son jóvenes y no hacen nada, sin embargo tuvimos que movernos a una tienda cercana a comprar fósforos, y durante el recorrido ellos se fumaron todo. Esta ha sido mi primera incursión nocturna en el barrio. (William, notas de campo, 2012)

El presente trabajo es un resumen de mi tesis de maestría en antropología intitulada: "Sobreviviendo con la pipa", drogas, violencia y conflictos inter-étnicos en el barrio El Paraíso", investigación realizada en la ciudad de Quito durante el periodo 2011-2013. Cerca de un año duró el trabajo de campo que conforma la columna vertebral de todo este texto, una etnografía en el sentido más clásico. Aquí intento abordar el problema de la precarización del trabajo que 
realizan un porcentaje considerable de afrodescendientes ${ }^{1}$ en las calles de Quito, y la forma cómo estos grupos étnicos se apropian del espacio, sus modos de producción, de socialización e interacciones inter-étnicas en su vida cotidiana.

Mediante la observación directa en un espacio determinado de la ciudad reconocido por su alto comercio, turismo y ocio, tuve mi primera aproximación al problema que concierne este proyecto. En esa primera experiencia me impresionó ver cómo en un espacio urbano delimitado se podían configurar distinciones sociales y culturales representadas en oficios laborales específicos, especialmente en la economía informal e ilegal, configurando a mi juicio jerarquías de clases, género y raza. Esta distinción la interpreté como una división étnica del trabajo y al mismo tiempo como la representación de una subalternización estructural, aspectos que han hecho del racismo, del estigma, la exclusión y la marginación social sobre minorías étnicas, una suerte de sentido común representada en las prácticas económicas y usos del espacio subalternos que tanto indígenas como afrodescendientes hacen de la ciudad. ${ }^{2}$

1 Indicadores sociales sobre pobreza y desigualdad en la población afrodescendiente indica lo siguiente: "Según la ECV del 2006 la población económicamente activa afroecuatoriana (PEA) supera el 71,64\%. Apenas igual a la PEA nacional (71,24\%). Pero al revisar las categorías de ocupación de la PEA afroecuatoriana encontramos que cerca del $36 \%$ está ocupada en actividades dedicadas a la agricultura, pesca, caza, venta al por mayor y al menor y servicios. En cambio apenas el 0,07\% se ocupa dedicado a servicios financieros e inmuebles. De acuerdo a los grupos de ocupación de la PEA ecuatoriana, se tienen los siguientes datos: apenas el 0,40 de la PEA afroecuatoriana está en el nivel directivo, gerente o administrador, en cambio en los blancos este nivel es del 1,37\%, siendo la media nacional del $0.91 \%$. Solo el $1,1 \%$ de la PEA afroecuatoriana se desempeña como profesional o intelectual, en los blancos este nivel es de 2,44, siendo el promedio nacional del 2,58. Apenas el 1,35 de los afroecuatorianos trabaja como empleado de oficina, en cambo los blancos están en el 3,33\%, siendo la media nacional del 2,33\%. En contraste el 19\% de los afroecuatorianos está en la categoría de trabajador no calificado, superando a los blancos con solo el 14,9\%, y la media nacional del 17,43" (Antón, 2011, p. 116).

2 Continuando con la cita anterior, esta desigualdad y diferencia étnica se puede explicar cómo nos dirá el siguiente autor de la siguiente manera: "En 
En un primer momento intenté describir el tipo de prácticas económicas que ambas minorías desarrollan, pero después de varios acercamientos fallidos con indígenas vendedores ambulantes en la calle desistí, y opté por enfocarme en el mundo afrodescendiente ${ }^{3}$ con los cuales tuve una mejor receptividad.

Al deambular por las calles de Quito y observar cómo en la mencionada división étnica del trabajo se formaban prácticas económicas diferenciadas por el uso del espacio pude ver dos tipos de distribución socio-espacial: 1) indígenas vinculados en el mercado informal, y 2) afrodescendiente en el mercado ilegal. Esta división se puede observar claramente en las relaciones cotidianas comerciales de toda la ciudad. Por un lado, indígenas vendiendo dulces (caramelos), cigarrillos, comida rápida, verduras, y por otro lado (y esto es la base fundamental de esta investigación), jóvenes afrodescendientes vendiendo drogas ilícitas como: marihuana, cocaína, y especialmente pasta base de cocaína. ${ }^{4}$

Ecuador se demuestra que los pueblos y nacionalidades poseen menos logros sociales respecto a la mayoría blanco mestiza. La explicación de esta disparidad exige tener en cuenta factores estructurales y coyunturales. La relación entre pobreza y etnicidad tienen su fundamento en el racismo estructural que se incubó desde la colonia y que relegó a estos actores como sujetos inferiores y con ciudadanía restrictiva. Pero, además, la desigualdad que enfrentan estos grupos es resultado de la presencia de factores excluyentes que impiden la satisfacción de derechos económicos y sociales por parte de una institucionalidad que restringe los recursos públicos, limita las inversiones y no democratiza la oferta de servicios básicos" (Antón, 2011, p. 118).

3 A lo largo de todo el texto se emplearán las categorías: afroecuatoriano, afroesmeraldeño y afrodescendiente.

4 Es una droga de bajo costo similar al crack elaborada con residuos de cocaína y procesada con ácido sulfúrico y queroseno. En ocasiones suele mezclarse con cloroformo, éter o carbonato de potasio, entre otras cosas. Es el residuo o la basura restante del proceso de elaboración de cocaína. En Colombia se le conoce con el nombre de bazuca en Ecuador como polva y en la Argentina como paco, en Brasil como crack. Para este trabajo he optado por denominar a esta droga como pasta base/ polvo 
De modo que me detuve en este hecho, puesto que la relación entre ilegalidad y etnicidad me planteó nuevas vías de investigación. A través de estas pequeñas notas etnográficas que registré en mi diario de campo sobre mis primeras impresiones de la ciudad y Ecuador, surgió la siguiente pregunta: ¿qué es lo que lleva a jóvenes afrodescendientes vender drogas ilícitas en la calle, y por qué ellos son más visibles que sus homólogos blancos/mestizos e indígenas? Paradójicamente esta es una pregunta que no se puede responder analizando únicamente la presencialidad de los hechos observados, sino necesariamente adentrándose en la historicidad de esta comunidad étnicas y su relación con la ciudad y construcción del Estado-Nación desde una perspectiva antropológica.

Estas preguntas no sólo forjaron un proyecto de análisis teórico, sino que principalmente me llevó a plantear una metodología que demostrará empíricamente lo postulado, para tal fin opté por el clásico método de la observación participante situándome en un barrio determinado de la ciudad reconocido por tener un alto grado de violencia y venta de drogas, además de un alto porcentaje de migrantes afrodescendientes de la costa pacífica ecuatoriana. Fue en este lugar donde residí durante un año participando en la vida cotidiana de un grupo de jóvenes consumidores/vendedores de pasta base de cocaína (en adelante pasta base/polvo) y otras actividades económicas informales/formales. Todo este proceso de investigación mejor conocido como etnografía es lo que constituye la base empírica de este trabajo. A continuación expondré de forma resumida la propuesta teórica, metodológica, una explicación de cada capítulo y fragmentos de los mismos que considero reveladores sobre el problema planteado, además de las palabras finales.

\section{El barrio, la calle, las drogas y el abordaje teórico}

El verdadero nombre de este barrio no lo puedo revelar por motivos de pertinencia, respeto y seguridad para mí y mis interlocutores. Pero tampoco quiero inventarme un nombre ficticio, así que lo llamaré 
El Paraíso, aludiendo al titular de prensa que encontré en un diario local que afirmaba lo siguiente: "El barrio; es el Paraíso de la droga".

El nombre de El Paraíso nos sirve a su vez como una metáfora para referirnos a la compleja historia de un lugar que con el pasar del tiempo ha vivido explosiones de violencia, pandillas, racismo, tráfico de drogas y pobreza, pero a su vez, un espacio social donde las ganas de vivir, salir adelante o simplemente sobrevivir; son un referente espacial y social de las grandes desigualdades estructurales aún existentes en el Ecuador del siglo XXI y la realidad urbana latinoamericana. Aunque el barrio a simple vista luce tranquilo, en su cotidianidad (especialmente nocturna) no tiene nada de paradisiaco, pero sí lo es para la economía ilegal, la informalidad y los consumidores/usuarios de pasta base/polvo.

No obstante este trabajo no habla exclusivamente sobre drogas o violencia. La mayoría de jóvenes con quienes interactué no le daban mucha importancia al tema, de hecho, en la cotidianidad, ellos trataban otra serie de asuntos como lo era el futbol: mujeres, experiencias laborales, sucesos personales o familiares. Las historias sobre droga, violencia e ilegalidades estaban destinadas a momentos esporádicos, íntimos y/o colectivos distantes de sus discursos en la esfera pública. Al convivir con ellos, lo que les interesaba mostrarme era cómo sobrevivían con dignidad en la ciudad, su lucha diaria contra la hostilidad urbana, la cultura serrana y su forma de convivencia.

Si bien la venta de drogas, la informalidad y la ilegalidad de los jóvenes que conforman este estudio son prácticas recurrentes en su cotidianidad, con ello no quiero decir "per se", que sea su principal recurso de subsistencia. La vida de muchos de estos jóvenes entrevistados pasa de largo sobre los clichés negativos del que se les acusa comúnmente, ${ }^{5}$ como también sucede con la violencia, consumo de drogas e ilegalidades en la totalidad del barrio, ínfimo, pero al que

5 Un buen ejemplo visual que profundiza sobre las raíces de la discriminación y el racismo en el medio urbano de Quito, lo ofrece el documental: 
sus moradores han generado tolerancia e indiferencia, sin que esto afecte su cotidianidad familiar, profesional y laboral.

Sin embargo, estas prácticas ilegales/informales describen un escenario de desigualdad estructural que históricamente ha afectado a poblaciones, territorios (provincias) y grupos étnicos (indígenas, afrodescendiente) más que otros. Por este motivo la hipótesis de este trabajo parte de tres categorías que considero relevantes para comprender las estrategias de supervivencia empleada por los jóvenes afroesmeraldeños con quienes compartí experiencias callejeras en El Paraíso, estas son: 1) administración de poblaciones ${ }^{6}$ (Guerrero, 2010; 2) violencia estructural ${ }^{7}$ (Bourgois, 2010) y; 3) Estado racial ${ }^{8}$ (Goldberg, 2002).

“¿Sospechosos?”, producido por la Corporación de Desarrollo Afroecuatoriano (CODAE) en el año 2010.

6 En la siguiente cita el autor describe cómo se construye esta categoría: En lo que se refiere a las poblaciones indígenas, su desaparición de lo público político es constitutiva de la construcción del Estado-nación ecuatoriano a lo largo del siglo xx. Por extraño que pueda parecer, la universalización esencializada de la ciudadanía bajo el modelo blanco-mestizo abrió hiatos de penumbra para ocultar (y sin embargo reconocer) dentro del mismo sistema político "la paradoja del indio", locución recurrente en boca de los políticos afines del siglo XIX. Desde 1827 hasta 1870, se utilizó una definición jurídica de excepción (a la vez inherente y constitutiva de la norma ciudadana) que los clasificaba por una figura de exclusión intrínseca al sistema: una noción específica, destinada a los individuos imposibilitados que no podían ejercer derechos y requerían de un tutor para ser representados. Dejaron de ser concebidos bajo el estatuto de "indígenas contribuyentes" (1857); fueron conceptual izados bajo la categoría de "población” o "personas miserables", por ende, sin plenos derechos ciudadanos (Guerrero, 1997, p. 3 ).

7 Opresión político-económica crónica y desigualdad social enraizada históricamente, que incluye desde acuerdos comerciales de explotación económica internacional, hasta condiciones de trabajo abusivas y altas tasas de mortalidad infantil (Citado en Bourgois, 2010, p. 14).

8 La siguiente cita es una traducción personal: Una de las evasiones más reveladoras en estas dos últimas décadas del pensamiento sobre la raza, ha afectado casi por completo el silencio teórico que hay sobre el Estado. No sólo la 
Los estudios recientes sobre formación del Estado nación ecuatoriano (Antón, 2011; Guerrero, 2010) han criticado la ausencia de la participación afrodescendiente e indígena en la constitución jurídica y burocrática de la naciente republica poscolonial del Ecuador del siglo XIX. En el caso de los indígenas, su palabra, discurso, incluso representación, era mediado por lo que Andrés Guerrero describe como ventriloquia (la cursiva es mía). Por lo tanto, su posición política y ciudadana estaba superpuesta a unas normas jurídicas y culturales subalternas respecto la dominación criolla blanco/mestiza, que para ese momento dirigían las directrices constituyentes de la esfera pública y política.

No obstante en 1857 se amplió la ciudadanía universal a los indígenas, y la administración de poblaciones estatal y privada perdió su hegemonía, en la escena cotidiana, aún ellos eran subalternos de un poder histórico estructural vertical que de modo cultural, económico (concertaje, huasipungo) y cognitivo, creó lo que señala Guerrero como una dominación por "sentido común”. Lo interesante de todo ello es que el autor no va más allá de la relación indígena-Estado, además, se sitúa principalmente en el territorio histórico estructural de los Andes equinocciales.

Este intersticio, digamos, ausencia de la relación afrodescendiente-Estado en el discurso histórico, es lo que me ha sugerido varias preguntas sobre la problemática afrodescendiente en relaciones a las condiciones públicas y políticas de los indígenas, ¿hubo una administración de poblaciones sobre la comunidad afroecuatoria-

forma en que el Estado está implicado en la reproducción de las condiciones más o menos locales de exclusión racial, sino, cómo el Estado moderno se ha concebido siempre como una configuración racial. El Estado moderno, en definitiva, no es nada menos que un estado racial. Es un Estado o un conjunto de condiciones ambientales socios específicos. Por lo tanto, en un sentido, no hay fenómeno totalizador singular que podamos nombrar Estado racial; más precisamente, hay Estado racial y Estado racista. Sin embargo, es posible, a la vez de insistir en que se dan las condiciones generalizables en virtud del cual el Estado moderno se concibe como racial y racialmente excluyente y racista. 
na?, ¿la ruptura de la esclavitud (1854) transformó a los afrodescendientes en ciudadanos con igualdad de derechos que sus homólogos nacionales? Tomando como referencia mis observaciones de campo y analizando los relatos de vida de mis interlocutores, la respuesta para la última pregunta sería negativa. Y en cambio para la primera podría explicarse a partir de la fragilidad del Estado de administrar geográfica y políticamente ese territorio.

De esta forma, las estrategias de poder para ejercer control o subordinación por parte del Estado y sus dirigentes blanco/mestizos, describe otra situación en relación con la experiencia de administración de población que hubo sobre comunidades indígenas. A largo plazo tal ingobernabilidad territorial consolidaría las bases de la actual desigualdad estructural de la provincia de Esmeraldas en relación a las provincias de las sierra, reforzando de este modo la incipiente ciudadanía ${ }^{9}$ afrodescendientes, en contraste con la población blanco/mestiza.

La abolición de la esclavitud y la ciudadanía universal para los grupos indígenas no deconstruyó las bases cognitivas, culturales, discursivas y raciales que durante siglos sostuvo el orden étnico/racial hegemónico y patriarcal blanco/mestizo, inclusive, se transformó en una forma de dominación pos-colonial mimetizada en la economía del huasipungo y el concertaje para mediados del siglo XX, inclusive hasta mucho después de su culminación. Estas eran otras prácticas de dominación pos-esclavistas que continuaron con la subalternización siendo obreros mal pagos en la económica de la hacienda.

9 Para John Antón: "Pese a que en 1854 se abolió definitivamente la esclavitud, aun los recién libertos afroecuatorianos no fueron considerados ciudadanos, pues muchos de ellos no sabían leer, no tenían propiedad y tampoco patrimonio económico. Muchos libertos se vieron obligados a nuevas formas de explotación como el concertaje, el huasipungo y la servidumbre doméstica. Allí los orígenes de nuestra desigualdad y exclusión” (Antón, 2011, p. 108). 
En la actualidad, las cifras describen un panorama preocupante para la población afrodescendiente, tal y como lo verán en la siguiente cita:

Según la ECV del 2006 la población económicamente activa afroecuatoriana (PEA) supera el 71,64\%. Apenas igual a la PEA nacional $(71,24 \%)$. Pero al revisar las categorías de ocupación de la PEA afroecuatoriana encontramos que cerca del $36 \%$ está ocupada en actividades dedicadas a la agricultura, pesca, caza, venta al por mayor y al menor y servicios. En cambio, apenas el 0,07\% se ocupa dedicado a servicios financieros e inmuebles. De acuerdo a los grupos de ocupación de la PEA ecuatoriana, se tienen los siguientes datos: apenas el 0,40 de la PEA afroecuatoriana está en el nivel directivo, gerente o administrador, en cambio en los blancos este nivel es del 1,37\%, siendo la media nacional del $0.91 \%$. Solo el $1,1 \%$ de la PEA afroecuatoriana se desempeña como profesional o intelectual, en los blancos este nivel es de 2,44, siendo el promedio nacional del 2,58. Apenas el 1,35 de los afroecuatorianos trabaja como empleado de oficina, en cambo los blancos están en el 3,33\%, siendo la media nacional del 2,33\%. En contraste el 19\% de los afroecuatorianos está en la categoría de trabajador no calificado, superando a los blancos con solo el 14,9\%, y la media nacional del 17,43. (Antón, 2011, p. 116)

En base a lo anterior, también podremos observar una gran diferencia de acceso al capital económico:

En Ecuador un hogar promedio obtiene ingresos mensuales medios por $\$ 522$, mientras en los afroecuatorianos los ingresos apenas alcanzan los $\$ 400$, en tanto un hogar blanco es el que más ingresos obtiene con $\$ 575,8$. En cuanto al promedio de ingresos por personas, la ECV determina que una persona blanca puede obtener ingresos medios laborales mensuales de $\$ 316,6$, en cambio un afroecuatoriano apenas logra obtener $\$ 210,8$, siendo la media nacional de \$268. Así mismo un blanco ubicado en el 5 quintil (más alto) puede obtener ingresos mensuales de $\$ 987$, en tanto un afroecuatoriano apenas alcanza a obtener $\$ 565$, siendo el promedio nacional \$800. (Antón, 2011, p. 115) 
101

Como se habrá visto en las anteriores citas, las diferencias estructurales están étnicamente diferenciadas de tal forma que:

En Ecuador se demuestra que los pueblos y nacionalidades poseen menos logros sociales respecto a la mayoría blanco mestiza. La explicación de esta disparidad exige tener en cuenta factores estructurales y coyunturales. La relación entre pobreza y etnicidad tienen su fundamento en el racismo estructural que se incubó desde la colonia y que relegó a estos actores como sujetos inferiores y con ciudadanía restrictiva. Pero, además, la desigualdad que enfrentan estos grupos es resultado de la presencia de factores excluyentes que impiden la satisfacción de derechos económicos y sociales por parte de una institucionalidad que restringe los recursos públicos, limita las inversiones y no democratiza la oferta de servicios básicos. (Antón, 2011, p. 118)

Lo expuesto encima proporciona al lector una aproximación a partir de datos estadísticos concretos que ayudan a sustentar la hipótesis planteada al inicio de este artículo, situándonos en las condiciones estructurales en la que se encuentran actualmente las minorías étnicas, especialmente población afrodescendiente. Y a su vez, estos datos y sus límites interpretativos fueron los que me motivaron no sólo a describir cualitativamente esta desigualdad, sino también analizar sus efectos colaterales como la ha sido y se podrá ver adelante, la expansión de la economía ilegal y criminal en el Ecuador del siglo XXI.

\section{El método}

Llegué a El Paraíso en junio de 2012 y salí de ahí en noviembre de 2013, sin contar los meses que pasé fuera del país en ese transcurso de tiempo, residí en el barrio de forma consecutiva durante un año. Durante la investigación conocí un sinnúmero de personas con historias, vivencias, sufrimientos, alegrías e ingenio impresionantes con los cuales compartía día y noche. Aclaro que no todos ellos me brindaban el mismo acceso y rapport en mi interacción con ellos, de modo que concentré mi etnografía en los interlocutores con quienes tuve mayor sinergia, pero sin acotar las decenas de notas de campo tomadas casi diariamente de los hechos, personas y vivencias tenidas con muchos 
otros jóvenes. Fue de esta forma que delimité y profundicé en las historias de vida de tres interlocutores que consideré claves para desarrollar este proyecto, ellos son: Richard, Guacho y Fabián.

Es por ello que considero el abordaje metodológico de este trabajo de vocación clásica, dado que no hay forma de conocer una cultura, un grupo étnico y hechos sociales sino es habitando su lugar de origen de forma prolongada, adentrándose en su lenguaje, creencia, prácticas y simbolismos, en mi caso esto significó vivir en El Paraíso.

Para la antropología y sociología urbana el clásico Street Corner Society de William Foot White (1993), es un ejemplo de cómo la entrada y residencia (inmersión) prolongada en un lugar puede desentrañar paradigmas culturales particulares. Sin embargo, la entrada a estos espacios y grupos puede estar medida por muchos factores, entre estos la suerte, un buen rapport o un ojo estratégico que pueda distinguir lo exótico de lo familiar (Geertz, 1996), tal y como explica Dennis Rodgers en su trabajo como antropólogo-pandillero en un barrio de Managua (Nicaragua).

Es primordial que el antropólogo pandillero viva en esa doble realidad durante un tiempo prolongado, para que lo cotidiano se haga explícito y para que lo que la gente dice que está haciendo se ponga a prueba en la vida diaria con lo que realmente está haciendo. Este contraste, importante para entender la organización de las vidas de los pandilleros, requiere de tiempo. Y requiere de inmersión en otro papel social. Inmersión, no conversión. En todos los momentos de la vida, todos jugamos varios papeles sociales, y un antropólogo, en el curso de sus investigaciones, tal vez juega más papeles aún. No deja de ser antropólogo cuando es pandillero ni tampoco se hace un pandillero exactamente como lo son los demás. (Rodgers, 2008, p. 4)

Como una estrategia de recopilación de información, desde mi iniciación en El Paraíso, describía diariamente los hechos que observaba en la cotidianidad de estos jóvenes en mi cuaderno de campo, además de mis experiencias de observación participante. La mayor parte de mis observaciones e interacción en el barrio se con- 
centró en una esquina (la cual doy por nombre la esquina del sabor) frecuentada por estos de jóvenes afroesmeraldeños en jornadas nocturnas interminables. También los acompañaba en sus quehaceres hogareños, fiestas en casa de brujos (microtraficante), transacciones ilegales, y pasar horas jugando billar, bebiendo o incluso; acompañarles mientras fumaban pasta base/polvo en pistolas ${ }^{10}$ con agilidad de mago, eran algunas de las tantas actividades en las que me encontraba de lleno, para después tomar los apuntes de regreso a casa $\mathrm{o}$, incluso, graba sus conversaciones cuando me era permitido. La sinceridad y el consentimiento informado me fueron muy útiles para desarrollar a plenitud esta labor etnográfica.

\section{Algunas notas sobre cada capítulo}

Esta tesis en su conjunto está conformada por cuatro capítulos de los cuales los tres primeros se componen de tres relatos de vida, lo que quiere decir que el núcleo de cada capítulo se centra única y exclusivamente en las experiencias de un personaje, relatos de vida diferentes que dan respuesta a tres problemáticas y alternativas de supervivencia. El cuarto capítulo discute aspectos más teóricos sobre la identidad y la diferencia, y tiene como eje central la voz de dos interlocutores. A excepción del cuarto capítulo los tres primeros se escribieron cada uno a cuatro manos en un proceso dialógico de ida y regreso, con lo cual le exponía, leía, precisaba, corregía y eliminaba cualquier información que no fuera de la aprobación de mis interlocutores.

\section{Guacho, "Este negocio es una puta película"}

Este parte de la historia de Guacho, un micro traficante de pasta base/polvo que inició su vida laboral en la industria camaro-

10 La pistola es el nombre que se le da a una forma de consumir la pasta base/polvo usando un cigarrillo. Se le da este nombre por la cantidad de humo que emana. 
nera. Procedente de la provincia Esmeraldas, ${ }^{11}$ Guacho nos describe en primera instancia la forma en que se ganaba la vida siendo adolescente. En esa etapa podremos ver las múltiples argucias desprendidas y articuladas de su economía informal y a su vez, los anhelos y sueños que llevan a una persona perfilarse hacia otras actividades, en este caso ilegales. También describiré los sucesos que le llevaron a perder su libertad, su experiencia en la cárcel y los motivos y estrategias actuales que emplea él para vender pasta base/polvo en la calle.

Él es un hombre de mediana altura, corpulento y aunque tenga 28 años parece que fuera aún más mayor. Esto se debe a su personalidad seria y reservada, muy diferente al resto de jóvenes coterráneos que viven en el barrio: espontáneos, divertidos y conversadores. La estética de Guacho se distingue de los otros porque viste siempre con ropa deportiva, por lo general de alguna marca prestigiosa (Nike, Adidas, Puma); en pocas palabras, él es un hombre impecable. Pero detrás de esa aura de misterio que proyecta hay una historia que describe los aconteceres vitales y estructurales que sufren y traen consigo muchos jóvenes migrantes que como él llegan a la ciudad de Quito.

Desde la edad de 12 años Guacho comenzó a trabajar en criaderos de camarón de medianas y grandes empresas; la recolección de mariscos, langostinos y pescados hacían parte de su faena diaria, como él mismo nos dirá; "en Esmeraldas trabajaba con los camaro-

11 La provincia tiene una población de 234511 habitantes y ocupa uno de los tres lugares más altos con Índice de Pobreza Humana en todo el Ecuador (IPH de 24.3 frente al 15.7 nacional -posición 13 de 15). Así mismo Esmeradas posee uno de los índices más bajos de Desarrollo Humano (0655 respecto a la nación de 0693). Estos datos dan cuenta del estado de pobreza y abandono en que se encuentra paradójicamente una de las regiones naturales más ricas del Ecuador en cuanto a recursos ambientales, biodiversos y marinos, dado que ella hace parte extensiva de la provincia Natural del Chocó biogeográfico. Esta información se puede encontrar en la página: www.siise.gob.ec. 
neros, íbamos a las piscinas y nos pasábamos la mañana llenando quintales de camarón”. Sin embargo, su posición laboral no se reducía únicamente a labores subordinadas de acuicultura, la seriedad y lealtad a sus patrones le situaban en otra posición de poder y agencia frente otros empleados.

Con el tiempo me hice pana de los duros, ellos me consideraban su mano derecha porque conocía la calidad del producto y traía más gente a trabajar, cada que íbamos a las piscinas me daban, 20, 40, 60 quintales de camarón aparte para yo vender. (Guacho, entrevista, 2012)

A pesar de su corta edad, esta forma de ganarse la vida le generaba semanalmente de 120 a 150 dólares. Tener una corta edad para él no representaba un impedimento en su economía de subsistencia, como nos relatará; "a los 12 años ya sabía cómo ganarme la plata, a esa edad yo andaba con manes ya sabidos aprendiendo mañas. Es que uno nace como con una virtud, uno es sabido" (Guacho, entrevista, 2012).

II

Dejando a un lado su infancia en Esmeraldas nos adentraremos a otra fase de la vida de Guacho que inicia al migrar a la ciudad de Quito. Jugar en un equipo de fútbol en Esmeraldas no le proporcionaba muchas esperanzas de progreso en esta profesión a sabiendas que los mejores entrenadores, condiciones físicas y apoyo financiero se sitúan en las capitales; "yo me vine a Quito donde una cuñada a entrenar porque acá están más avanzados, yo siempre he querido ser grande, lamentablemente me caí y todo se fue a la mierda" (Guacho, entrevista, 2013).

Pero a diferencia de sus otros parientes, su cuñada y hermano residentes en la ciudad llevaban a cabo actividades económicas ilícitas, Guacho dirá:

Mi cuñada es traficante de las grandes, mi hermano también, pero solo de base, ellos me mantuvieron un rato, pero yo no iba vivir esperanzado de ellos ya con 18 años, me quería vestir bien y tener mis cosas, ella me dijo que si quería le ayudara a camellar con merca, 


\section{6}

entonces desde ahí me puse a traficar, me compré un carro, luego otro, a los 19 ya tenía dos carros a nombre de mi madre, vendía por kilo. (Guacho, entrevista, 2012)

Al poco tiempo de migrar a Quito paso a paso Guacho se convertía en un traficante de pasta base/polvo, vendiendo drogas por kilos y al menudeo, no obstante, en ese punto aún él no se consideraba brujo, porque, además, combinaba la venta de drogas con la delincuencia; él nos dice:

Con mis primos y un sobrino salíamos con un cuchillo a robar pura pinta buena, en esas anduve como tres meses, al norte no íbamos porque hay mucha ley, salíamos era de noche a las discotecas a robar borrachos (Guacho, entrevista: 2012).

En el 2004 los equipos pagaban a los jugadores que estaban en reserva 120 dólares mensuales para su manutención personal, sin embargo, esa cantidad de dinero no era suficiente para Guacho, en especial cuando el coste de vida en la ciudad de Quito es más costoso que en otras ciudades. Pero él siempre ha encontraba la forma paralela de aumentar sus ingresos, esto facilitaba su ayuda a otros jóvenes jugadores que como él proyectaban ser grandes promesas del fútbol:

El Banguera me preguntaba siempre cómo hacía yo para estar bien vestido, me veía con las chicas, para ese momento tenía dos carros, como lo veía necesitando le daba dinero para comer, que comprara ropa, por eso él cuando me ve no duda en tenderme la mano. (Guacho, entrevista, 2013)

Pero la ficción alrededor del bienestar material y su estética cegaban los riesgos socio-jurídico al que está expuesta cualquier persona actuando al margen de la ley. Y pese el cuidado de Guacho en mitigar su exposición como traficante, delegar sus bienes a nombre de su madre y luego de su pareja, esto no impidió que un socio celoso lo delatara ante la policía y le siguieran durante dos semanas para que luego antinarcóticos le hiciera un operativo de captura. Guacho sería capturado en el año 2004 cerca de cumplir 19 años. 
William: ¿Cómo es que te atrapan?

Guacho: Un amigo me delató, me cogieron con 3 kilos

William: Y... ¿por qué te ha delatado?

Guacho: por sufridor, yo trabajaba solo con manabas (riendo) y era el cabecilla. A mí me veían vacilar bacano, entonces varios manes se sumaron trabajar conmigo. A los amigos les prestaba la casa, el carro, les daba comida, de todo les daba. Pero el man que me sapeó no me daba confianza. Una vez no le di un trabajo, entonces el man se ardió conmigo, por eso me sapeó, me acuerdo bien, fue un martes 13 de julio. Ese día yo me iba a trabajar, durante una semana me habían seguido, por confianzudo me cogieron, cargaba 3 kilos de polvo.

Foto 1

Guacho en su territorio

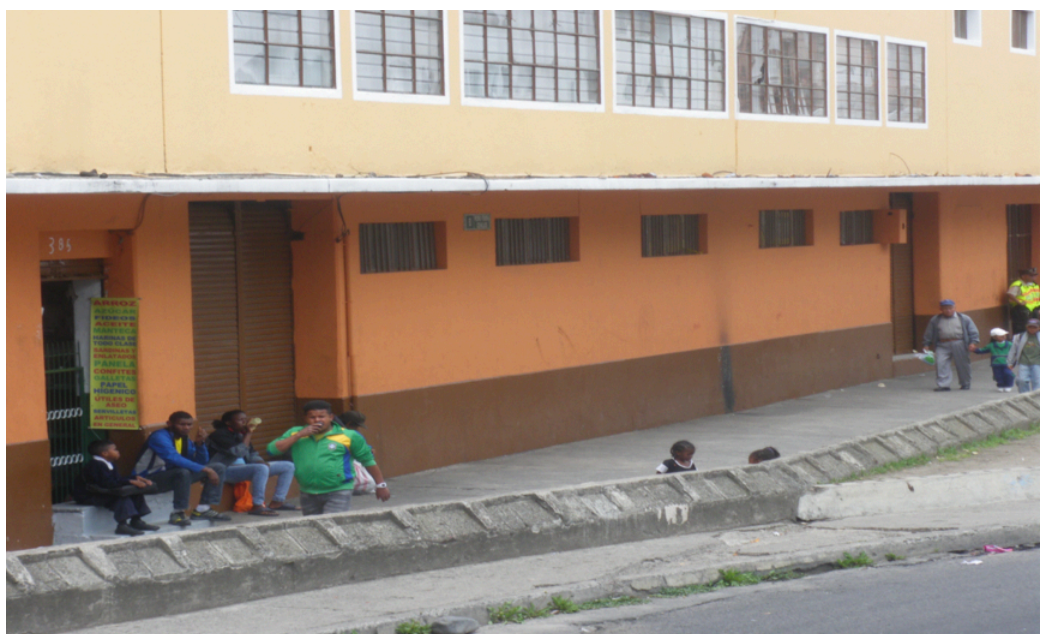

Fuente: William Álvarez

III

$\mathrm{Al}$ recobrar la libertad Guacho regresó a la casa de su cuñada, pero su mujer se había ido con otro hombre con el poco dinero que le quedaba. Desde que él entró a la cárcel ella le dio la espalda deshaciéndose poco a poco de sus bienes. Para Guacho el negocio de la 
droga no es para todo el mundo y cualquiera está expuesto a caer preso alguna vez en su vida. En la cárcel él aprendió quiénes son los verdaderos amigos, en su caso solo su madre le visitaba, ni siquiera su pareja, lo irónico es que después de él salir a los tres meses ella cayó presa, pero a diferencia de ella él sí le visita y lo hace con la única intención de demostrarle que nadie es invencible, y que aún en la adversidad él le demuestra su solidaridad.

La solidaridad es un valor que en el mundo de la venta de drogas y en el consumo de la misma es irrelevante, incluso traicionero. El canibalismo y el ganar siempre al otro son prácticas recurrentes para sobrevivir en la calle. Guacho tuvo que recurrir a su familia para volver a levantarse, el único vínculo de ayuda en quien él puede confiar.

William: ¿qué hiciste al salir de la cárcel?

Guacho: En los primeros cinco meses me quedé sano, mi hermano y cuñada me mantuvieron hasta ver cómo estaba la cosa con mi seguridad, necesitaba ver si la policía aún me seguía el rastro, luego me puse a traficar otra vez. (William, entrevista, 2012)

Después de su experiencia en el penal, Guacho volvería a vender pasta base/polvo, pero ahora desde un perfil más bajo, resarciendo sus equívocos pasados:

Antes yo andaba confiado con mucha droga encima, inocente, ahora solo ando con lo mío por si mi coge la ley decir que es para mí consumo. Lo que pasa es que antes la ley no era tan experimentada, yo solía andar con mi canguro lleno de droga y plata, ahora si te ven por ahí medio sospechoso te cae la ley, más si eres negro: la ley es más sabida. (Guacho, entrevista, p. 2013)

Las prácticas ilegales de venta de Guacho son totalmente opuestas a la manera en que otros brujos y brujitos comercializan las sustancias ilícitas en las márgenes de El Paraíso, su estrategia es otra y se funda en los aprendizajes adquiridos, digamos, capitalizados en la cárcel; "los otros brujitos no saben nada, se la votan por la plata, yo tengo lo mío, hago lo mío, escondo lo mío en la casa, trabajo para mí solo; trabajo solo para no tener pitos con nadie" (Guacho, entrevista, 2012). 


\section{9}

De este modo Guacho salvaguarda su pellejo de los errores pasados que le privaron la libertad, en especial, el de trabajar colectivamente.

Pero las estrategias de supervivencia de Guacho no se centran únicamente en la económica ilícita, su habitus económico varía dependiendo de las circunstancias, sabe a la perfección que es un negocio al cual no se quiere dedicar toda su vida y para ello tiene pensado; "seguir vendiendo hasta final de año (2013), lo que quiero es montar una línea de zapatos originales a crédito, vender por catálogo para cobrar semanalmente, pero estos giles del barrio no se les puede vender, están chiros siempre" (Guacho, entrevista, 2013).

Durante el tiempo que pasé en El Paraíso, en varias ocasiones fui a comer a un restaurante de su propiedad localizado en un pequeño centro comercial cerca al barrio, cuando Richard me comentó de su existencia no me lo creía, de modo fui a comprobarlo en persona con tan buena suerte que Guacho al verme me convido almorzar. Pero este restaurante en realidad solo es una fachada, como argumenta él:

Este negocio es una puta película, ahí no tengo es nada, pero sí vendía buena comidita costeña, eso no daba mucho, sin embargo, cuando la gente iba siempre estaba cargado, muchos solo iban por eso, me llamaban y yo llevaba la cantidad: 10, 20, 30, dólares, no vendía menos, cargaba lo pedido, ahí llegaban abogados que compraban 30, 40 dólares, almorzaban y se llevaban lo suyo. (Guacho, entrevista, 2013)

El Paraíso es un barrio seguro en el que Guacho se siente protegido. Con cerca de 12 años viviendo en sus entrañas, él ha vivido y observado las transformaciones en su interior, y en esencia, conseguido legitimar su presencia y ganar el respeto de otros brujos. Para él:

Este barrio es nombrado, mucho delincuente, mucha droga, El Paraíso es el barrio más nombrado, siempre ha sido así, luego sigue San Roque, La Libertad: la ley siempre está por acá. Hace cinco años había más pandillas, Los chamos, yo era de esa pandilla, el jefe era el gato, él se fue para España y allá lo mataron. Era una banda de 
unos ciento treinta manes. Por eso acá me conocen: nadie se mete conmigo. ${ }^{12}$ (Guacho, entrevista, 2012)

En la actualidad y según relatos de viejos vecinos de El Paraíso, el poder que ejercían las pandillas y con ellos la violencia y la miseria que se vivía en las calles ha disminuido comparativamente a lo que era hace unos diez años, pero esto no quiere decir que la venta de drogas también haya cesado, en perspectiva de Guacho:

Acá hay más gente vendiendo droga por espacio cuadrado que en todo Quito. Es que es muy buena plaza por ser centro y porque también hay mucha corrupción. La ley llega a las nueve de la mañana, yo estoy desde antes, pero aun así no me confío. (Guacho, entrevista, 2012)

Pero cuando la ley captura alguien es fácil encontrar una salida, que como en el caso de Guacho al cargar con pocas papeletas de pasta base/polvo, puedes salir bien librado.

William: ¿Se puede tranzar con la ley?

Guacho: Depende, si te cogen con 15 paquetes te sueltan, tú solo dices que eres consumidor. Esos manes también fuman, a veces solo te esculcan para tener algo que fumar, pero si te haces el resabiado, el bravo, te pegan. (William, entrevista, 2012)

\section{Richard, “arrechera”}

En este aparte me enfoco en el relato de vida de Richard, un joven afroesmeraldeño que migró a la ciudad de Quito a causa de una extorsión violenta y al mismo tiempo por cobrar la vida de una de las personas que lo violentó. Sin embargo, la violencia con la que él se ha rodeado no es el único referente de su vida, sino la trayectoria que después de este suceso ha hecho de su cotidianidad un referente de subsistencia polifacético, visceral e ingenioso de las múltiples estrategias de supervivencia que puede adquirir una persona en situaciones conflictivas y vulnerables.

12 De hecho, el que me vieran andar con Guacho me facilitó la confianza y protección de conocer otros brujos. 
Para este propósito hago una trayectoria de su vida desde el momento en que él migró hacia la ciudad de Quito, además de un resumen de sus actividades laborales sean estas formales/informales o legales/ilegales para sobrevivir. A través de su historia pretendo mostrarle al lector qué tipo de argucias debe adquirir un afroesmeraldeño migrante para sobrevivir en una ciudad que odia, pero a la cual le debe la vida, el bienestar de su pareja e hijo.

Desde el primer día que conocí a Richard no me ha dejado de asombrar sus múltiples formas de ganarse la vida en todos los aspectos de la economía, pasando por lo legal/formal, a lo ilegal/informal, un constante ir y venir entre las márgenes de polos opuestos, pero a su vez imperantes dentro del sistema productivo.

Durante mi estadía en el barrio su principal ingreso económico lo obtenía de la venta informal de comidas. Todas las noches desde las 5 de la tarde hasta pasada las 9 de la noche disponía de un puesto de comida sobre una esquina concurrida del barrio para ofrecer su producto a un precio de un dólar o dólar y medio de forma rápida y fácil de llevar. Por medio de ese puesto de comida se ganaba la vida y sostenía un hogar constituido por su mujer (Rebeca) e hijo de 4 años. En promedio, diariamente vendía cincuenta o sesenta unidades de comida que le dejaban de ganancia de veinticinco a treinta dólares libres. Pero la venta neta podría llegar a cien, ciento veinte, ciento treinta unidades, dependiendo del día.

Cuando Richard vivía en Isla Bonita (Esmeraldas) realizaba labores económicas de toda clase (formales e informales) en base a la oferta real de trabajo: pesca, agricultura, turismo y venta de artesanías eran las labores que él desempeñaba. Pero su principal fuente de dinero inició con la venta al por mayor de camarones a grandes hoteles en Atacames (Esmeraldas) como dirá a continuación:

Arranqué vendiendo camarón en pequeñas cantidades a comerciantes del pueblo, yo no pescaba, le compraba a un conocido que me 
vendía barato y como intermediario vendía más caro, por ejemplo, de un quintal (50 kilos), sacaba 15-20 dólares, ahí estaba el negocio, luego me hice de un contacto en un hotel y empecé a venderle 10, 20, 30 quintales, hasta más, y como la venta era buena, le daba un porcentaje a mi amigo para que me diera el mejor producto, entonces comencé a venderle a los hoteles Resort y ganaba buen dinero. (Richard, entrevista, 2012)

Sin embargo, esta bonanza económica estuvo opacada por el aumento de la violencia cotidiana (Scheper-Hughes, 1997), la intimidación y la extorsión que se vivía en Esmeraldas. La envidia y la sospecha que produjo Richard alrededor de su mejoría económica trajeron consigo una persecución secreta por parte de una banda de extorsionistas. Una noche dos hombres se presentaron a su casa fuertemente armados agrediéndolo a él y su pareja, a ella le amarraron mientras Richard se resistía y le golpeaban. El objetivo de la banda de extorsionistas era hacerse con el dinero que Richard guardaba en su casa, pero como él no accedía, le cortaron lentamente un extremo de oreja, Richard lo describió así:

Yo no iba dejar me quitaran mi dinero, bravié con todos dos, me dieron con el mango de la pistola, pero aun así resistía hasta que me tumbaron y amarraron las manos. Como yo no quería decir nada me amenazaron con cortarme la oreja, pero no comía de esa presión, entonces me pusieron sobre una mesa y uno de esos manes cogió un cuchillo y me preguntó por última vez dónde estaba el dinero, me volví a resistir y fue ahí donde empezó con el cuchillo a torturarme, ya no aguantaba, entonces les entregué el dinero (Richard, entrevista: 2012).

Después de este suceso Richard quedo ofendido y como la justicia según sus palabras "no sirve para nada" en Esmeraldas, él tomó la venganza en sus propias manos. Luego de indagar en las cercanías del pueblo sobre los extorsionistas, dio con uno de ellos al cual asesinó, pero el otro escapó. Richard no pudo recuperar los 15 mil dólares que le robaron, y estos ajustes de cuentas le obligaron migrar a la ciudad de Quito. 
Cuando llegué a Quito lo primero que conseguí fue un trabajo en una papelería que era conocida de mi hermano, la dueña al rato de conocernos resultó ser familia lejana. Yo no estaba familiarizado con nada ahí, pero hacía de todo, hasta lo que no sabía; prender computadoras, sacar copias, barría, atendía clientes. La dueña me cogió mucho apreció y ayudó económicamente, pero yo ya estaba aburrido ahí, eso no era lo que me gustaba y como tenía problemas en la casa, renuncie. (Richard, entrevista, 2012)

A Richard le costó seguir subordinado, de modo que desistió de ese empleo. Al cabo de unos días Richard había dejado la casa de su hermano y mudado a un cuarto en el barrio que compartía con otros jóvenes afroesmeraldeños, también migrantes, entre ellos su primo Genaro y la Belleza. ${ }^{13}$

Junto con otros jóvenes afroesmeraldeños migrantes armaron una red de apoyo, y un lugar de residencia. Entre todos ${ }^{14}$ se dividían los gastos de alimentación (que en el peor de los casos se basaba en migas de pan y agua panela), renta y gastos de servicios públicos (agua, luz). Algunos como el primo de Richard y la Belleza ganaron algo de dinero jugando en la B de la Liga Deportiva Universitaria de Quito. Pero las exigencias nutritivas de este deporte estaban por encima de las capacidades reales mínimas de carbohidratos necesarias para reponerse y rendir las exigencias diarias del cuerpo. Los pagos se demoraban en llegar y tampoco cubrían lo necesario para durar hasta fin de mes.

La incidencia de estos aspectos lleva a que las calles de Quito se convirtieran en un escenario ideal para resolver sus necesidades básicas; cada uno por su lado o de modo colectivo, la delincuencia es una respuesta obligada ante tantos instrumentos legales/formales.

13 Ambos, llegaron a Quito por dos motivos, la Belleza huyendo a la cárcel que le esperaba por intento de asesinato y porte ilegal de armas, y Genaro, por líos de faldas y ajuste de cuentas con bandas criminales.

14 Un número variable pues la casa estaba abierta al recibimiento de jóvenes provenientes de Esmeraldas sin casa. Al mismo tiempo se iban rotando las plazas por las concurridas salidas del lugar por razones laborales o provisionales. 
En una ocasión, en la esquina del sabor, los jóvenes hacían memoria de los asaltos, la Belleza me preguntó de modo natural, “i¿es que tú no robas parce?!", al escuchar mi negativa frunció el ceño incrédulo. La naturaleza de su expresión y la comodidad con la que narraba sus experiencias violentas, naturalizan un habitus que desde su economía política de la vida transforma las acciones delictivas de una visión ética negativa, a una práctica viable éticamente permisible a su condición estructural que no necesariamente asocia delito con despilfarro y gastos banales, como nos comenta Richard:

Una vez yo estaba en la mala mala, Rebeca estaba a punto de parir y yo sin plata, una tardé salí a caminar la Amazonas y vi salir de un banco a un japonés, lo seguí un rato y llegando a un parque le cogí por la espalda y quité el maletín, cuando llegué a la casa me encontré con 1600 dólares, con esa plata compré las cosas del bebé y pagué el parto, adelanté arriendos, me surtí de comida, pagué deudas, incluso invité a beber y comer a los amigos. (Richard, entrevista, 2012)

Además de esta perspectiva de entender las razones que motivan el crimen, con frecuencia en los relatos de otros jóvenes al igual que Richard, encontré muchas experiencias violentas en la interacción barrial de estos jóvenes con la policía, es decir, lo que sucede en las márgenes de lo legal e ilegal en la vida cotidiana de personas que como él están situados en la periferia del Estado. El Estado corporizado en la praxis policial es el generador principal de las fricciones socioculturales que desencadenan y expanden la violencia estructural reflejada en estallidos brutales de violencia urbana. El caso de Richard es particular dado que en varias oportunidades se ha enfrentado cuerpo a cuerpo con ellos. En una ocasión lo hizo en defensa propia cuando le intentaron desalojar de los alrededores de la estación céntrica de transporte de la Marín por hacer uso indebido del espacio público con su venta informal de comida rápida con la cual se ganaba la vida:

Una vez en la Marín me sacó la policía casi que a patadas, me tocó guardar las cosas rápido orque se estaban llevando todo lo que estuviera en la calle invadiendo; al que se pusiera bravo le echaban gas 
pimienta. Conmigo se prendió un agente a echarme como animal y yo me le paré convidándolo pelear como hombre, pero como estaba con mi hijo me apresuré dejarlo en la entrada del barrio porque estaban tirado gases lacrimógenos. (Richard, entrevista, 2012)

La "arrechera" del momento llevó a Richard sacar el machete que cargaba al interior de su carrito de comida y responder con violencia sus ataques:

A mí esa injusticia y atropello me arrechan, ya cuando vi que mi hijo estaba arriba saqué el machete y me les enfrenté a los manes. El que me quería ver cara de gil le clavé el machete entre el cuello y el hombro. Apenas vi que él sacaba su arma agarré a correr esquivando los disparos. Llegué a la tienda de un amigo donde guardé el machete y me hice una calle más arriba donde los panas, y como muchos ya habían visto el atropello de estos manes, los sacamos a punta de piedra. (Richard, entrevista, 2012)

Las ocasiones en que la policía me detuvo en el barrio estando con Richard y otros jóvenes merodeando sus calles, nunca lo hicieron con la intención de llevarnos presos, ni tampoco lo hicieron de forma violenta. Cuando esto sucedía Richard era el primero en dar la cara, para luego regresar diciendo.

Muchos de los jóvenes migrantes afroesmeraldeños que conocí en el barrio habían tenido o continuaban teniendo algún tipo de relación con el tráfico ilícito de pasta base/polvo. Para Richard la venta de drogas fue una entrada importante de dinero durante un tiempo, según él; "vender polvo es un buen negocio socio, deja mucho dinero, pero también es riesgoso, desgastante". Dentro de la esfera de actividades que ha realizado Richard para sobrevivir, la venta de drogas no ha sido aislada, pero tampoco ha sido una actividad de su preferencia, sino sucesos esporádicos y coyunturales. 
La misma noche que la policía hiciera el operativo de control sobre el espacio público en el barrio, en tono desesperado y molesto él me expuso lo siguiente:

Hey pana, la verdad... me gustaría ahorrar un buen dinero para dejar mi familia montada y luego amarrarme una bomba al cuerpo para acabar con todos esos hijueputas, ya nos los soporto hermano, voy a tener que volver a vender drogas, llenarlos toditos de polvo, pues ya no puedo, tengo deudas pendientes, ahora mi hijo va al colegio y ya necesita de los útiles... Yo esperaba pararme esta semana con la venta, pues como tú sabes, por ayudar a mi cuñado me quedé sin dinero. (Richard, entrevista, 2012)

Richard tiene contactos suficientes para comprar cualquier tipo y cantidad de droga, sin embargo, y luego que se le pasara la rabia del incidente, él argumenta que volver a vender polvo ya no es una opción. En el caso de Richard, el factor que más influyó para dejar la calle tuvo relación con el nacimiento de su hijo. Con mucha insistencia en varias conversaciones que tuvimos, él hacía un fuerte énfasis en que su hijo era la razón de su vida y el principal pretexto desde el día en que nació de volverse legal. Entre los jóvenes que conocí existía una gran diferencia entre quienes eran padres y quienes no lo eran. El habitus delictivo de los últimos tendía a medir menos el riesgo en las actividades ilegales, incluso, tenían mayor motivación para hacerlo, mientras los primeros evitaban en lo posible volver a la delincuencia, incluso, alentaban a sus congéneres moverse de la economía ilícita a la legal.

Durante mi último mes de incursión en el barrio Richard pasaba más tiempo en la esquina esperando cualquier oportunidad de hacer algún cruce que vendiendo comida. Los últimos altercados con la policía y un daño que provocó el choque ${ }^{15}$ del automóvil de un

15 Para Richard este accidente fue un pretexto, con ello evitó trabajar una semana esperando le pagaran 120 dólares que según él cubrían los costos sobre los daños del puesto de comida, además, sumada la mercancía perdida. Pero el puesto de comida no sufrió mayor daño, él sobredimensionó el acci- 
vecino a su puesto de comida, lo desalentó y desmotivó seguir en ese rebusque. Después de este incidente Richard no volvió a vender comida en la esquina. Aburrido por tanta persecución policial y aprovechando la ayuda de sus amigos, él consiguió un empleo temporal como obrero en una construcción.

\section{Foto 2}

Richard y su esposa en la esquina

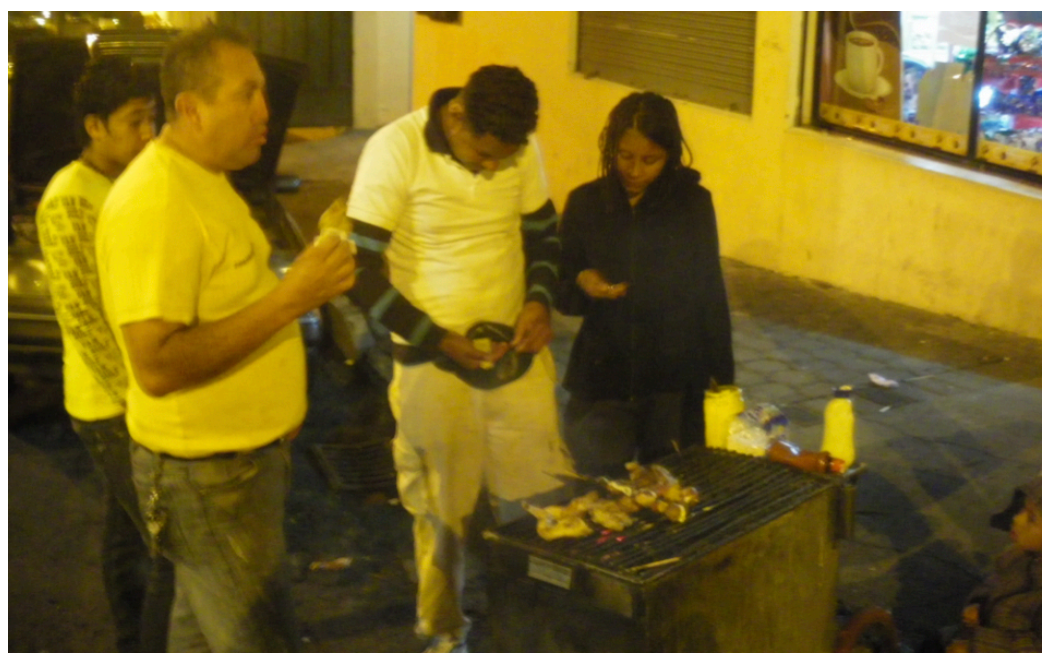

Fuente: William Álvarez

Para diciembre del 2012 Richard ya había dejado por completo la venta ambulante de comida, sobre esta decisión él responderá; "ya me salí de ese negocio socio, me tiene aburrido esa hostigadera, quiero hacer otras cosas, en esto no me desgasto tanto, aunque tenga que ir lejos y cumplir un horario" (Richard, entrevista, 2012). En su nuevo

dente y por esos días sin trabajar perdió más dinero de lo que recibiría en una jornada de trabajo. Las ganancias diarias pueden variar entre 40-80 dólares según el día de la semana y del tiempo que dedique a la venta. Haciendo una estimación media, es posible que Richard, durante el tiempo no laborado por el pretexto del accidente, dejó de percibir durante esos días: 150 -200 dólares. 
trabajo le estaban pagando entre 120 a 150 dólares por semana. Sin embargo, Richard no consiguió encontrar estabilidad en la construcción de un solo golpe, de hecho, tuvo problemas desde un principio porque no le pagaban a tiempo, los trabajos eran temporales, cosa que le afectaba ya que tenía deudas atrasadas.

En el caso de Richard vender comida informalmente en la calle o ser obrero de construcción, representan actividades ajenas al peligro de las acciones ilegales y de la carga moral que le representa situarse en dicho espacio como única estrategia económica de subsistencia. Sin embargo, este tipo de sucesos que pueden ser frecuentes o esporádicos en los migrantes afroesmeraldeños ahonda en el estereotipo que sobre ellos se imagina, mediatiza, se habla; remarcándolos negativamente, en suma, criminalizándolos.

\section{Fabián, echando humo con la pipa}

Este apartado se aleja de los dos anteriores. La historia que teje el hilo conductor es un joven consumidor de pasta base/polvo con el cual quiero describir el otro lado de la realidad del barrio, el de los consumidores consumados ${ }^{16}$ y ya no tanto la realidad de brujos ${ }^{17}$ (Guacho) o vendedores ocasionales de droga (Richard).

16 Esta es una categoría con la cual describo a un tipo de consumidor de drogas, específicamente de pasta base de cocaína. En el trabajo de investigación con el cual se sustenta este ensayo, hago una diferencia determinante entre usuario y consumidor de drogas ilícitas. Un usuario puede conectarse o desconectarse regular o irregularmente del uso de sustancias tóxicas, lo que lo diferencia del consumidor, quien sostiene regularmente el consumo de tóxicos como parte de su rutina, pero quien aún tiene un cierto control y conciencia sobre sí mismo y su cuerpo, pero en el caso de los habitantes de calle, ambas categorías no se ajustan a su condición. Es por ello que hago uso del término consumidor consumado, para explicar y describir el alcance que produce el consumo en exceso de la pasta base de cocaína, la dependencia, adicción, perdida de conciencia sobre el sí mismo y el valor del cuerpo. Los consumidores consumados son diestros y expertos sujetos dedicados día y noche dedicar su vida al consumo y metafóricamente, consumirse en la pasta base de cocaína.

17 Brujos y brujitos son dos categorías empleadas en Ecuador para nombrar a los sujetos encargados de vender cualquier tipo de drogas. Se puede entender como el anglicismo "dealer". 
A través de este relato se quiere desmitificar el imaginario o estigma que se tiene sobre los consumidores de drogas habitantes o deambulantes de la calle. En El Paraíso hay muchos, pero al convivir con ellos breves estancias es posible adentrarse a conocer otro tipo de economía y supervivencia ajena al cotidiano normatizado. Con el relato de vida de Fabián desmiento aquellos discursos que satanizan la pobreza como la gestora del crimen, la violencia y las adicciones. La entrada al consumo y callejización no radica tanto en factores estructurales como el ser pobre, hay otras coyunturas tales como el desamor, la soledad o posiciones ideológicas que empujan al individuo tomar este tipo de caminos antagónicos, a este respecto: la cultura (o subcultura) callejera.

La descripción etnográfica que hago del habitus de consumo de drogas de Fabián nos aproximará a conocer la economía política construida alrededor de este habitus, en suma, un motivo de gran importancia que estructura la cotidianidad de muchos consumidores que no necesariamente acuden al crimen, la violencia e ilegalidades para satisfacer sus ansias y necesidades vitales. En este capítulo podremos observar otras estrategias de supervivencia, recursividad, ingenio y lógica económica imperceptible, casi que impensable del lado de la legalidad, pero complementaria de la economía callejera.

Por otro lado, se describirá la materialidad con que el consumo de pasta base/polvo se efectúa, la estética y rituales necesarios realizados por los consumidores consumados para preparar una pistola o pipa (formas de consumo) con los cuales, metafóricamente: consumir-se.

La expresión del título surgió una noche en que me encontré a Fabián en el callejón fumando polvo incansablemente, en su mano izquierda tenía una herida infringida días antes en una pelea que él no buscó, tenía vendado su mano y desde la última vez que nos topamos me pareció verle curado, de modo que lancé la siguiente expresión; "te veo mejor Fabián”. Él me quedó viendo pensativo, “¿mejor dice usted?”, 
exclamó, -sí... Luces mejor, respondí yo. Aclaro que con esa expresión me refería a la herida de su mano, pero para él este comentario se dirigía más a su condición de vida que a la herida en sí misma. Con ello lo único que pude forjar en Fabián, sumada la excitación que la droga le infringía; fue un sentimiento de culpa, sufrimiento y frustración que durante la noche desahogó en mi compañía.

La iniciación al consumo de pasta base/polvo tiene muchas características, entradas, acercamientos, incluso niveles de consumo complejos de establecer, a este respecto el consumo depende esencialmente del habitus y el espacio social que incluye diferencias de clase, etnia y género, además del territorio. Por lo tanto, las mencionadas categorías son las que en buena parte repercuten en la producción de un habitus que por lo general se inscribe dentro o fuera de una sociedad funcional-estructurada. Sin embargo, un consumidor de pasta base/polvo no solo responde a un espacio social de producción de habitus de forma estructural, de ser así caeríamos en el simplismo reduccionista de la teoría de la desviación y la ceguera de la criminología clásica, como también en el cliché de la cultura de la pobreza de Oscar Lewis (1966).

Él es un joven afrodescendiente que migró a la ciudad de Quito en búsqueda de mejores condiciones de trabajo y las encontró en una microempresa dedicada a producir todo tipo de publicidad en papel. A su llegada a la ciudad le costó obtener reconocimiento para ganarse su puesto de trabajo, luego de vencer sus limitaciones respecto al ritmo laboral, cultural, además de la discriminación racial; él se volvió un referente técnico en el área de impresión mecanizada, tanto fue su éxito que otros empresarios de la publicidad lo disputaban, dado su excelente desempeño y eficiencia.

Luego de haberse consolidado en el manejo de la maquinaria publicitaria el dueño de la imprenta le respaldó aumentando su sueldo, lo que se tradujo en ganancias que triplicaron su básico inicial de 250 a 800 dólares mensuales. En realidad, sumando el trabajo extra y esporádico, la suma rodeaba los 1000 a 1200 dólares mensuales. Para 
ese entonces cuando la abundancia le cobijaba formaba una familia con una joven quiteña quien le dio una hija. Hasta ese momento Fabián no hacía uso de ningún tipo de drogas, de hecho evitaba los lugares y personas que en el barrio Miraflores (centro de Quito) tenía algún vínculo con ese mundo, su habitus estaba focalizado en el trabajo y la familia.

Sin embargo, la estabilidad conseguida comenzó a tambalear cuando una mañana la maquinaria que frecuentaba usar se averió, imprevisto que le forzó tomarse el resto del día aprovechando la ocasión. Fabián regresó a recoger a su hija para llevarle al jardín, tarea que hacia su esposa, pero él no pudo abrir la puerta debido a que ésta estaba bloqueada por dentro, ni tampoco respondieron al timbre, razón que le obligó saltar la pared del patio para entrar en ella. Ya adentro Fabián encontró a su mujer teniendo relaciones sexuales con un vecino conocido. El impacto de aquella escena caló tan hondo en él que lo único pudo responder fue un "te amo" con la voz entrecortada y a punto de llorar referido a quien consideraba en ese momento su esposa. Desde ese día Fabián no volvería hacer él mismo comenzando así un progresivo declinamiento social, personal y humano que me reclamó justamente aquella noche "trikiado ${ }^{18 "}$ en exceso por el polvo; "no diga que estoy bien pana ¡Mírame!, me encuentro peor" (Fabián, entrevista, 2013).

Este suceso lo ha llevado a consumirse en sí mismo encontrando en el polvo una posible sanación, en su caso: al olvido. Pero recurrir a la pasta base/polvo fue lo último en que pensó y cuando le conoció tuvo un proceso de subidas y bajadas hasta llegar a ser lo que considero en mis propios términos: un consumidor consumado.

Antes que nos encontráramos y me relatara de golpe todo lo anterior, además de querer engañarme (para sacarme dinero) y ba-

18 Expresión utilizada por los consumidores para hacer referencia al estado alterado que produce consumir pasta base/polvo. "Embale", también es una expresión muy utilizada. 
jar su nivel de ansiedad; su pretensión era desahogarse del recuerdo provocado de golpe por la visita inesperada de un conocido de su ex compañera, quien vino al callejón a buscarle.

William: Después de todo lo pasado, ¿ella vino a buscarte?

Fabián: No pana, mandó una pinta, no sé si sea su novio o marido nuevo, me dijo que me quería ver.

William: ¿Qué le contestaste?

Fabián: (Con rabia) Le dije, jlárgate de aquí chucha tu madre y dile que no se le ocurra venir a buscarme porque la mato, soy capaz de matarla!

William: Me doy cuenta que aún te duele recordarla.

Fabián: ¡Cómo no pana si ya no puedo ni ver a mi hija!

William: $\mathrm{Y}$ desde que vives en la calle, ¿le has visto?

Fabián: Al principio sí, me sentía digno, no estaba tan basureado como ahora. Cuando me siento triste la espero fuera del colegio y le veo de lejos, es duro no querer acercarme (Fabián, entrevista, 2013).

II

En varias ocasiones he podido seguir de cerca la cotidianidad de Fabián desde su despertar. Una mañana le fui a buscar para invitarle desayunar, lo encontré durmiendo bajo unas casetas que a su vez están debajo de un puente que circunda el barrio. Él guardó las cobijas y dobló su colchón improvisado haciendo un bulto que luego dispuso bajos unas cajas. Junto las casetas hay varios negocios de costura, como siempre Fabián saludó amablemente a sus dueños y luego entró al baño público a lavarse la cara. El pan y el yogurt que le ofrecí Fabián no lo comió de inmediato, sino después. ${ }^{19}$ Él conoce prodigiosamente la periferia comercial del barrio a pesar de ser nuevo ${ }^{20}$ en El Paraíso, pero a diferencia de otros consumidores consumados Fabián ha consolidado una red de solidaridad o benevolencia con los comerciantes,

19 Mientras se está consumiendo pasta base/polvo, se pierde el hambre.

20 Esta categoría se ha convertido en un signo de distinción, no obstante llevé cerca de dos años en el barrio, para los otros consumidores consumados él sigue siendo nuevo. 
dueños de negocios, vendedores ambulantes, quienes le facilitan alguna moneda, comida, ${ }^{21}$ incluso algún cruce o favor especial.

Fabián es consciente que sus prácticas difieren de otros que están a su vez consumados en la calle, pero a diferencia de los otros él discierne sobre el estado en que se encuentra lo que ha hecho trasformar la lástima, la vergüenza y la pena; en dignificarse sin importar su condición de paria. Mirar a la cara y saludar cordialmente con buenos días/tardes/noches a todo aquel que le observa, le conozca, hasta los vecinos cerca al callejón ha hecho que lo vean de forma diferente lo que se traduce en afectos de solidaridad: alguna moneda, ropa usada, alimentos. Sin embargo, aunque en un principio su economía callejera tenga visos de dependencia solidaria por su condición de callejizado, su economía va más allá y denota estrategias bien elaboradas de subsistencia o rebusque adquiridos en la calle. A esto lo podemos considerar como un capital cultural adquirido, incluso heredado de formas de sacar provecho de los insumos materiales presentes en lo urbano.

\section{Foto 3}

Fabián preparando su pipa para fumar

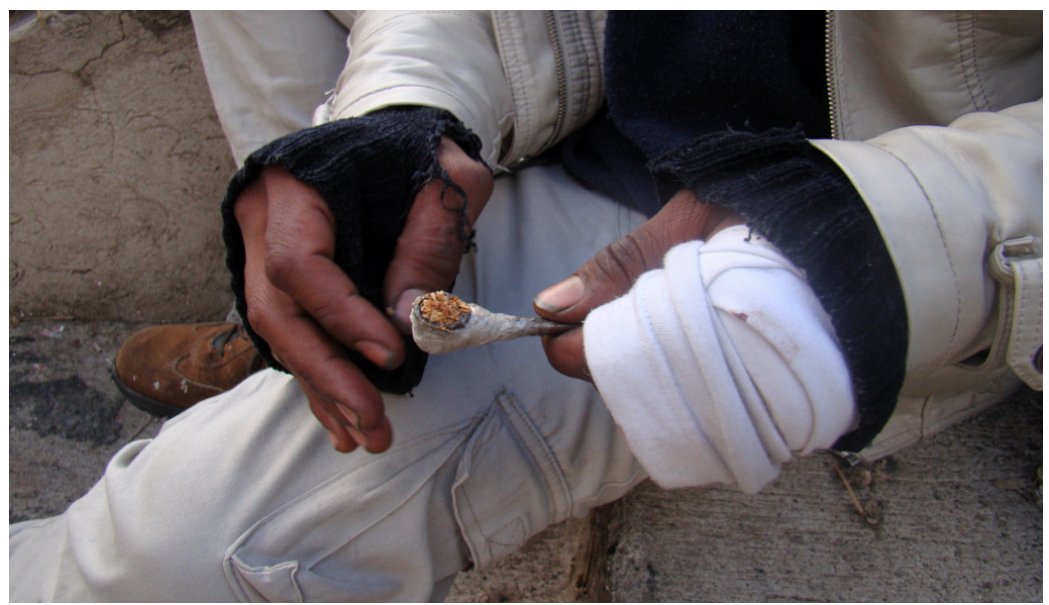

Fuente: William Álvarez

21 La dueña de una panadería le regala pan todas las mañanas. 
La recolección de basura es una de las prácticas frecuentes que desarrollan los consumidores consumados para conseguir dinero. Saben muy bien dónde encontrar objetos de valor en la basura o comida. De hecho, cuando Fabián recién comenzaba a vivir en la calle se encontró con otros como él que le señalaban los lugares estratégicos como restaurantes y hoteles en los cuales podía hallar comida en buen estado, ropa, sabanas y enceras desechables. Según explica Fabián muchos de estos desechos son arrojados a la calle de buena fe por sus dueños con el fin de proveer necesidades materiales y vitales a los recicladores (consumidores).

De modo que la noche o la madrugada se convierten en el tiempo propicio de muchos consumidores para rebuscarse y encontrar en la calle elementos para sobrevivir. Cabe apuntar que esta búsqueda hace parte del tiempo de consumo consumado en su cotidianidad que a su vez responde al tiempo de consumo al que su cuerpo se ha inscrito. Digamos, el que se rebusca en la noche no responde a preferencias horarias, sino al efecto atemporal en que su cotidianidad responde al consumo. Hay que indicar que para los consumidores consumados no hay un tiempo límite de consumo, existe por lo tanto una dependencia crónica a la pasta base/polvo que lleva al cuerpo/sujeto distorsionar el tiempo biológico haciendo del tiempo de consumo: una acción interminable.

Mientras otros consumidores pueden estar robando o intimidando a personas en lugares como la calle Amazonas, plaza Marín, o el barrio La Ronda. La economía política de Fabián desentraña y produce otras redes económicas fuera de lógicas violentas o criminales para satisfacer su consumo personal. Puede que alguna noche consiga hacerse amigo de alguien que le convide fumar subido en un automóvil dando vueltas en la ciudad o haya encontrado un teléfono obsoleto en la basura, lo arreglara y vendiera alguna persona. Ambas situaciones son reales y en mencionados relatos de Fabián han hecho parte de su historia de vida desde que habita la calle. Sin embargo, aunque Fabián declare abiertamente que no sirve para robar, cabe 
preguntarse, ¿el estar en condición de calle, ser un consumidor consumado de drogas ilícitas; conlleva a producir violencia cotidiana? (Scheper-Hughes, 1997).

En una ocasión le pregunté a Fabián si robaba para sobrevivir, él aludió la respuesta con otra historia, pero nunca contestó afirmativo-negativo. Meses después una tarde le encontré en el callejón preparando una pipa con otros dos jóvenes. Me acerqué a él recibiéndome con un gran abrazo y una pipa cargada hasta el tope convidándome a fumar, a sabiendas que no lo hago.

William: ¿Qué tal Fabián?

Fabián: (Abrazo) ¡Ohh hermano!, necesitaba hablar con usted, ¿se acuerda lo que le dije aquella ves de esta chica?

William: ¡Si claro!... ¿Qué ha pasado?

Fabián: (Insiste con la pipa) ¡Me intentaron apuñalar hermano!

William: ¿Qué ha pasado?

Fabián: (Prendiendo la pipa para otro) Arriba estaba con dos manes y ella que me pasa la pipa llena con un hachís gomoso, cuando le prendí olía a caucho y no carburaba, así que no fumé, pero como me cayó la sospecha le pasé la pipa a los otros dos. Como yo venía caliente por lo del Toni, alegué con ella y el otro que estaba ahí me sacó un cuchillo para darme, pero él estaba intoxicado, no daba con el cuerpo, entonces la vi a ella y me dieron ganas de encenderla a puñete. ¡Hermano! Yo no sé cuál es su afán de joderme siempre.

William: ¿La chica no te dio hachís?

Fabián: (Fumando pipa) No pana, yo no sé qué era eso, pero yo estaba reputo hermano, y sí no llega la policía quién sabe qué hubiera pasado. Vieron el cuchillo en el piso y me quisieron llevar preso porque la otra estaba inventando que yo era el que le iba apuñalar. (Fabián, entrevista, 2013)

Al concluir este diálogo Fabián me contó que sintió igual de nervios como cuando robó por primera vez un teléfono a alguien en la calle. Visto de ese modo la etnografía prolongada desmiente omisiones que los sujetos tratan de omitir moralmente por sentirse juzgados. 
Cuando Fabián se dispone a prender su pipa agrega el polvo con cautela sacudiendo sobre ésta la papeleta o funda de plástico con pasta base/polvo. Rellena toda la pipa procurando no desperdiciar, así, la economía del consumo proporciona otros pipasos a futuro. Antes de consumar el ritual observa de lleno el contenido de la pipa, con un fósforo encendido ${ }^{22}$ (sin aspirar aun de la pipa) circula el polvo para comprobar su calidad, sí el polvo se granula o derrite y emite su olor característico, se le fuma con mayor o menor gusto. "Cuando le quemo es para secarlo, el polvo seco mejora la sensación” (Fabián, entrevista, 2013), dice Fabián.

A diferencia de la pistola, la cual se puede rellenar con una sola papeleta de polvo, misma cantidad que puede dar de 3 a 4 pipasos. ${ }^{23}$ Esto hace de la pipa la forma de consumir pasta base/polvo que más adicción genera, dado que un solo pipaso, según lo describe Fabián el sabor del polvo se potencializa y aunque el efecto no sea tan prolongado como la producida al fumar en pistola, varios pipasos suplen la cantidad por mejor calidad. He aquí la trampa que produce el fumar en pipa y la razón del miedo que genera en personas como Richard cruzar este límite. Para Richard "el que fuma en pipa ya está cogido por el demonio". Y de esto son conscientes los consumidores consumados que como Fabián alguna vez han arrojado su pipa al hacer consciente el nivel de degradación al que han llegado.

William: ¿Solo fumas en pipa?

Fabián: Eso depende, fumo en cualquier cosa, tú mismo me has visto, hasta en zanahorias. Pero veras... la pipa, no sé, me gusta más porque disfruto del sabor, hago que sea más prolongada mi fuma-

22 El uso de los fósforos llama mucho la atención. ¿por qué no usar fosforeras o encendedores? La respuesta sobre esta pregunta los consumidores consumados concluyen; el gas del encendedor les produce sueño.

23 Expresión utilizada por los consumidores para nombrar las bocanadas de humo extraídas de la pipa. 
da, en cambio con la pistola se desperdicia, aunque es más fuerte, y mientras fumo en la pipa, dura y se siente mejor.

William: Tengo mis dudas, ¿la pipa te da más ganas de fumar?

Fabián: Verás... te dijera mentira si digo lo contrario... la pipa es el diablo. (Fabián, entrevista, 2013)

\section{"Allá uno vive más tranquilo, más relajado compita"}

Aquí sólo describiré por tratarse de un abordaje más conceptual, me adentro en las dificultades de las relaciones inter-étnicas de los jóvenes afroesmeraldeños en relación con la cultura serrana urbana. En una primera instancia, haciendo uso de una entrevista a profundidad realizada a Richard y Rebeca (esposa de Richard) se describirán los aspectos culturales para ellos considerados básicos que establecen las diferencias entre serranos y costeños, y el por qué de los conflictos inter-étnicos producidos alrededor de estas diferencias en El Paraíso.

Luego entraremos a discutir la problemática que representa el concepto de interculturalidad a partir de las vivencias, experiencias, discursos y posiciones regionales expresadas por estos jóvenes, problematizando de esta manera la interculturalidad funcional (Walsh, 2009) propendida por el Estado ecuatoriano, la cual, en teoría, argumenta la existencia de relaciones horizontales entre los diferentes grupos étnicos o nacionalidades.

Para concluir, en la última parte de este capítulo profundizo en las complejidades discursivas, culturales e identitarias que representan y construyen lo étnico. Para ello, me centro en tres categorías: afrodescendiente, negro y montubio. Y, a partir del discurso identitario de Richard expongo la volatilidad de dichas categorías, como también la de-re-construcción subjetiva y polifacética que implica, primero; la identidad y segundo, una adscripción étnica, que en el caso de los jóvenes afroesmeraldeños conocidos en mi labor de campo; están por fuera de cualquier proceso social o movimiento político de reivindicación identitaria. 


\section{Palabras finales}

Este trabajo es la muestra de un "conocimiento situado" que ha tenido como objetivo principal develar una realidad desentendida por la antropología (urbana) ecuatoriana contemporánea, sobre las condiciones de vida, el sufrimiento humano y las estrategias de supervivencia que aún muchos ecuatorianos/as en el siglo XXI se ven obligados a realizar como los mencionados afroesmeraldeños; debido al abandono, olvido y desidia de un Estado racial, pero sobre todo, a una violencia estructural histórica global que ha privilegiado la hegemonía de unos sobre otros.

Al llegar hasta a este punto muchas cosas han pasado en El Paraíso, Richard abandonó por completo la vente informal en la esquina del sabor, de modo que la congregación de amigos y conocidos afroesmeraldeños no tiene la misma frecuencia y concentración como cuando Richard tenía su puesto de comidas. A finales del mes de enero de 2013 Richard aún no tenía una actividad económica definida, su pareja era quien se encargaba económicamente de él y los gastos del hogar. De vez en cuando Richard pintaba casas y también ejercía como maestro de construcción, pero solo eran trabajos momentáneos, incluso, estaba esperando le confirmaran un empleo en una petrolera del oriente amazónico (la cual le pagarían 600 dólares mensuales trabajando 20 días y descansando 10), pero al final esto no se pudo dar.

Guacho no ha cambiado mucho, sigue acudiendo a la misma hora en las márgenes de El Paraíso a vender pasta base/polvo, también se ha mudado un poco más al sur de la ciudad a una casa más bonita, barata y tranquila que la habitada en El Paraíso; "ñaño, en el sur pago menos, sí me hace falta el barrio y espero volver, pero donde estoy tengo cable y puedo ver todos los partidos de la liga española" (Guacho, entrevista, 2013), explica Guacho de su motivación por mudarse del barrio.

Desde que su hijastra salió de vacaciones del colegio él llega al barrio solo en las tardes, hace sus cruces y luego se va entrenar fútbol. 
Él no ha vuelto a tener problemas con la policía. En varias ocasiones me lo he encontrado en la esquina del sabor hablando con sus amigos y coterráneos, no pierde oportunidad de ver algún partido de fútbol con ellos. Sigue en pie su iniciativa de dejar de vender pasta base/polvo para finales del año 2014.

La historia de Fabián también ha tomado otro rumbo. Justo después de terminar el tercer capítulo leímos juntos los resultados, a él le gustó y me dio algunas recomendaciones extras, pero al momento de describir textualmente lo que le hizo su expareja, él estuvo a punto de llorar y prefirió que pasará la hoja. Una semana después lo encontré bajo el puente donde solía dormir; "vea pana (señalándome un hueco sin cicatrizar en su cuello), esto me hicieron allá en el callejón dos negros amigos de la Miriam, casi me matan, pero me pude zafar y pelear contras los manes" (Fabián, entrevista, 2013), describiría él sobre el intento de homicidio que sufrió pocos días después de leer juntos el tercer capítulo. Este incidente lo obligó internarse en el hospital, estar medicado, alejarse de la pasta base/polvo y la violencia de la calle. Tiempo que aprovechó para re-pensar su vida.

Verle en proceso de sanación y transformación personal me llenaba de satisfacción en contraste con la cotidianidad de los otros consumidores consumados que frecuentan el barrio. No obstante, a medida que pasaba el tiempo las ideas de cambio en Fabián volverían a esfumarse entre pipas, pistolas y polvo. Su nuevo hogar se convirtió en un lugar codiciado por otros usuarios de pasta base/ polvo que escapan del aumento reciente de la represión policial. A finales de agosto de 2013 visité a Fabián, después de su atentado ya estaba del todo recuperado y de regreso al consumo de polvo, esa tarde cumplía tres días sin dormir y aprovechó para narrarme sus últimos sucesos eróticos y conflictos con otros consumidores consumados. Su monólogo reflexionaba sobre su trayectoria y frustración al no poder cumplir sus anhelos de cambio, sobre este aspecto él se definirá como un "guardián cósmico": 
Fabián: ¿Sabes a qué me refiero con esto?, me lo acabo de inventar, me siento como un guardia que vigila entradas, estoy entre un mundo que ya veo de lejos, pero al que no puedo encontrar el equilibrio entre lo que me dicen los otros de cómo estoy, el cómo debería sentirme respecto esos halagos y mi imposibilidad de coincidir esa imagen con la que tengo actualmente, yo no quiero estar basureado, pero este mundo del polvo es raro y ahora siento que lo circulo.

William: ¿Querrás decir un vicio de respeto?

Fabián: ¡No pana! Es un mundo raro porque al final no sabes en qué estas ni a dónde vas (Fabián, entrevista, 2013).

Para el mes de noviembre Fabián había sido desalojado de su cuarto por la policía, sus pertenencias fueron quemadas y la puerta de entrada clausuradas con cadena y candado. Para la policía ese lugar se había transformado en un refugio de adictos y delincuentes, pero Fabián no lo veía de ese modo. Él volvió a la calle y con ello al mismo habitus que casi le quita la vida.

La venta de drogas ilícitas en el barrio se mantiene y cada vez son más los nuevos individuos que hacen presencia en sus márgenes. La mayoría de jóvenes brujitos, incluso brujos en El Paraíso (hombres, mujeres) han estado presos durante este año, pero poco tiempo después de salir vuelven a la calle, retoman su habitus de consumo y sus estrategias de supervivencia. Por desgracia, la adicción que genera la pasta base/polvo y su dinámica sociocultural en muchas ocasiones pueden más que la voluntad de buscar un camino alternativo, porque, además, la ayuda del Estado es incipiente en esta área.

Ante la pregunta formulada en la introducción; ¿qué lleva a jóvenes afrodescendientes vender drogas ilícitas en la calle, y por qué ellos son más visibles que sus homólogos blanco/mestizos e indígenas? Los tres relatos de vida que componen este trabajo describen buena parte de las condiciones estructurales que empujan de múltiples formas a los jóvenes afroesmeraldeños tener que inclinarse hacia economías ilícitas e informales como un recurso de supervivencia. 
Por otro lado, la migración de afroesmeraldeños ha aumentado y su presencia en el barrio sigue siendo notoria. He conocido algunos jóvenes que en su mayoría recurren a la venta informal de dulces en el trasporte público y la calle, pero también a la delincuencia estratégica. Estos nuevos migrantes, al igual que Guacho y Richard recurren al capital delictivo $\mathrm{u}$ habitus ilegal como estrategias de supervivencia dentro de las varias formas de ganarse la vida entre lo legal/formal e ilegal/informal. Algunos se quedan en esferas ilegales, pero como lo he descrito en los relatos anteriores, muchos prefieren u optan por formas no violentas ni ilegales de sobrevivir empleando el ingenio o la recursividad (en el caso de Richard) para lograrlo.

\section{Bibliografía}

Antón, J. (2011). El proceso organizativo afroecuatoriano: 1979-2009. Quito: Serie Atrio.

Bourgois, P. (2010). Más allá de una pornografía de la violencia. Lecciones desde el Salvador. En C. F. (Eds.), Jóvenes sin tregua. Culturas y políticas de la violencia (p. 237). Barcelona: Anthropos.

(2010). En busca de respeto, vendiendo crack en el Harlem. Buenos Aires: Siglo XXI editores.

Geertz, C. (1996). Los usos de la diversidad. Barcelona: Paidós Ibérica.

Goldberg, D. (2002). The Racial State. Malden: Blackwell Publishers INC.

Guerrero, A. (2010). Administración de poblaciones, ventriloquia y transescritura: Análisis histórico: Estudios teóricos. Lima: IEP, Flacso sede Ecuador.

Lewis, O. (1966). La vida. A Puerto Rican Family in the Culture Of Poverty-San Juan and New York. Nueva York: Random House.

Rocha, J. L., \& Rodgers, D. (2008). Bróderes descobijados y vagos alucinados: una década con las pandillas nicaragüenses, 1997-2007. Managua: Envío.

Scheper-Hughes, N. (1997). La muerte sin llanto: violencia y vida cotidiana en Brasil. Madrid: Ariel.

Walsh, C. (2009). Hacia una comprensión de la interculturalidad. Tukari, 6-7. 